\title{
MĚŘENÍ SPOTŘEBY VODY NA POTRUBÍ K ZÁSOBOVÁNÍ WC V BUDOVĚ INTERNÁTU
}

\author{
MEASUREMENT OF WATER CONSUMPTION ON THE SUPPLY OF THE \\ WC BOARDING SCHOOL BUILDING
}

Jan Moštěk ${ }^{*}, 1$

${ }^{*}$ mostek.honza@seznam.cz

${ }^{1}$ Fakulta Stavební VUT v Brně, Veveři 331/95, 60200 Brno-střed

\begin{abstract}
Abstrakt
$\mathrm{V}$ příspěvku byly uvedeny poznatky z výzkumu měření průtoku v objektu internátu u učiliště v Brně při všech dnech měření. V první části př́spěvku je popsáno měření průtoků v objektu internátu. Měření bylo provedeno v roce 2019 a úkolem bylo zjistit rentabilitu při využívání srážkových vod pro rozvod provozní vody k zásobování WC. V druhé části př́ispěvku je provedeno vyhodnocení naměřených dat v jednotlivých dnech z měřeného objektu. V třetí části článku byla provedena diskuze vyhodnocených výsledků a v závěru př́íspěvku bylo provedeno shrnutí autorem.
\end{abstract}

\section{Klíčová slova}

Maximální průtok, vnitřní vodovod, průtokoměr, spotřeba vody

\begin{abstract}
The paper provides findings from research on flow measurements in the premises of the boarding school in Brno at all measurement days. The first part of the contribution describes the measurement of flows in the premises of the boarding house. The measurement was carried out in 2019 and the task was to determine the profitability of the use of rainwater for the distribution of working water for the supply of WC. In the second part of the contribution, an evaluation of the measured data on a day-by-day basis from the measured object is made. The third part of the article will discuss the evaluation results and the conclusion of the contribution is a summary by the author.
\end{abstract}

\section{Key words}

Maximum flow, water installation, flowmeter, water consumption

\section{1 ÚVOD}

Měření průtoků provádíme pro potřeby úpravy stanovení výpočtových průtoků, pro zjištění spotřeby vody v řešených objektech a přesnější návrh zásobníkových ohřívačủ teplé vody.

Měření průtoků na vnitřních vodovodech v různých objektech v České republice není z důvodu různých překážek možné. Překážkami jsou především nesouhlas vlastníků objektu, ve kterém by se mohlo měření na vnitřním vodovodu provádět (nesouhlas s osazením průtokoměru). Nemožnost osazení průtokoměru do potrubí nebo připojení měřící ústředny na elektrickou energii a zajištění uzamykatelné místnosti, z důvodu ochrany měřící ústředny. Měření tudíž provádíme především pří různých př́ležitostech a opravách vnitřních vodovodů v objektu.

V roce 2019 bylo provedeno měření v objektu internátu pro středoškolské studenty, kde se provádělo měření průtoků na potrubí vnitřního vodovodu zásobujícím pouze nádržkové splachovače na WC. Úkolem bylo zjistit spotřebu vodu pro WC v objektu. A analyzovat př́padnou rentabilitu při využívání srážkových vod pro rozvody provozní vody k zásobování nádržkových splachovačů na WC.

\section{POPIS SOUČASNÉHO STAVU}

V dané kapitole je popsán skutečný stav na měřeném objektu. 


\section{Měření v objektu internátu pro středoškolské studenty}

V objektu internátu pro středoškolské studenty proběhlo měření od 12. 3. do 26. 3. 2019. Měření proběhlo na potrubí zásobujícím nádržkové splachovače na WC v řešeném objektu. Měřící zařízení průtokoměru bylo umístěno na jednom ze stoupacích potrubí zásobující nádržkové splachovače na $4 \mathrm{WC}$ u pokojů internátu a $1 \mathrm{WC}$ v hygienickém zařizení pro vrátné. Kde na každém pokoji jsou ubytováni 2 studenti (celkem 8 studentů ve čtyřech pokojích) a na vrátnici jsou předpokládány 1 až 2 osoby. V místnosti s osazeným průtokoměrem byla umístěna měřící ústředna, která byla připojena k průtokoměru Obr. 1 [1].

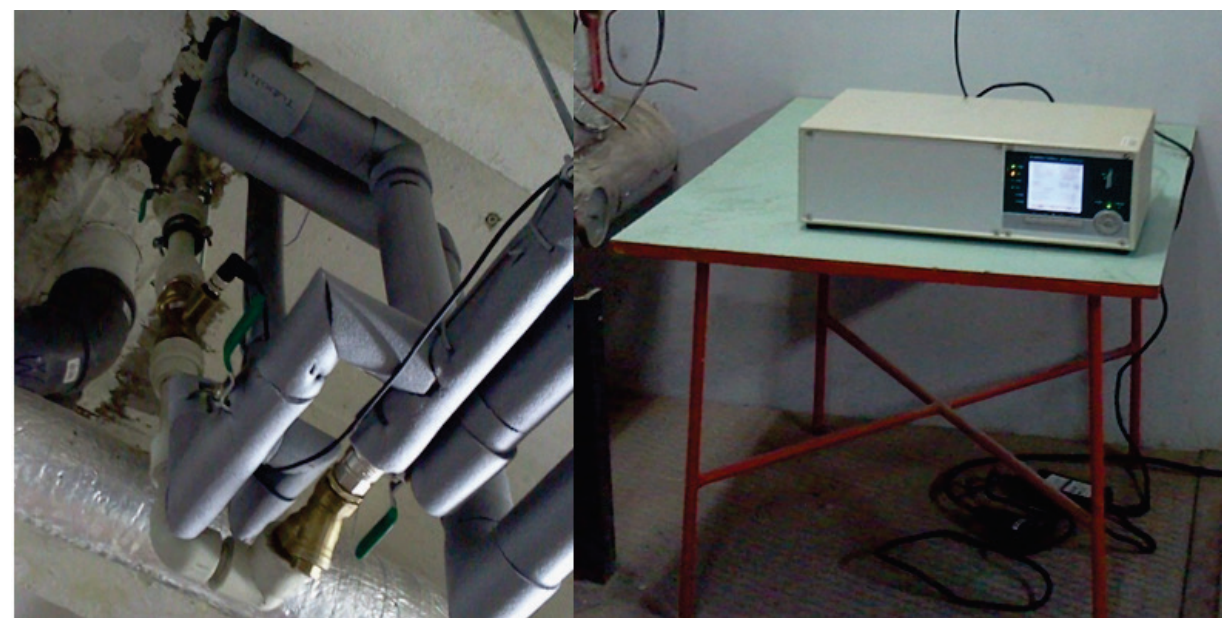

Obr. 1 Osazení průtokoměru AHLBORN ALMEMO FVA915VTH25, měřící ústředna AHLBORN ALMEMO 5690-2 v objektu internátu pro středoškolské studenty.

\section{METODIKA}

Při provádění měření průtoku v různých objektech provádíme měření pomocí průtokoměru připojenému k měřící ústředně. Měření musí být prováděno po dobu nejméně 14 dní, aby byla naměřená data dostačující k analýze doby maximálních změřených průtoků [1].

Pro měření na řešeném bytovém domě byl použit mechanický lopatkový průtokoměr, který funguje na principu působení dynamického tlaku vody na oběžné kolo. Otáčivý pohyb lopatkového kola je snímán.

Při prováděném měření je měřící ústředna vždy nastavena k měření průtoků trvajících jednu sekundu. Při daném nastavení zařízení se musí v průběhu měření data ukládat. Aby se zmenšila pravděpodobnost chybného ukládání dat, provádíme při jejich sběru kontrolu zařízení a tím eliminujeme možnou chybu.

Následuje ukládání posledních naměřených dat a odpojení měřící ústředny s měřícím zařízením.

Dále provádíme ukládání naměřených dat do počítače s následným roztříděním dat podle dnů měření a vyhodnocení naměřených výsledků. Vzhledem $\mathrm{k}$ nastavení měřící ústředny s ukládanými daty můžeme provádět mnoho vyhodnocení různých výsledků. $\mathrm{V}$ daném výzkumu se provádělo měření průtoku na vnitřním vodovodu v objektu internátu učiliště v Brně. Vyhodnocení výsledků výzkumu se provádí tabelováním hodnot s následným grafickým vyhotovením naměřených dat.

\section{VÝSLEDKY}

V objektu internátu pro středoškolské studenty proběhlo měření od 12. 3. do 26. 3. 2019. Maximální špičkové průtoky naměřené $\mathrm{v}$ jednotlivých dnech $\mathrm{v}$ objektu internátu pro středoškolské studenty činily hodnoty od 0,2-0,67 1/s. Průtok 0,67 1/s byl naměřen ve čtvrtek 21. 3. 2019 a trval 1 sekundu. Jelikož je daný výsledek ve velkém nepoměru s ostatními dny měření, proto $\mathrm{v}$ této části provádím porovnání s druhým nejvyšším průtokem 
0,372 1/s naměřen v pondělí 18. 3. 2019. Spotřeba vody v řešeném objektu v jednotlivých dnech činila hodnoty 0-262 1/den. Průměrná spotřeba v objektu byla 152 1/den.

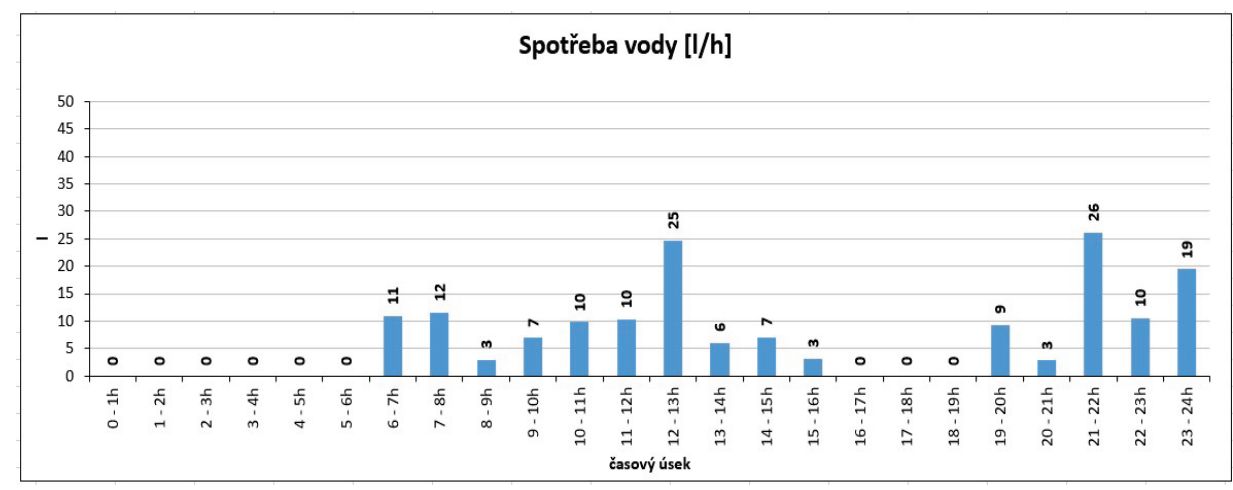

Obr. 2 Spotřeba vody 1/den - pondělí 18. 3. 2019.

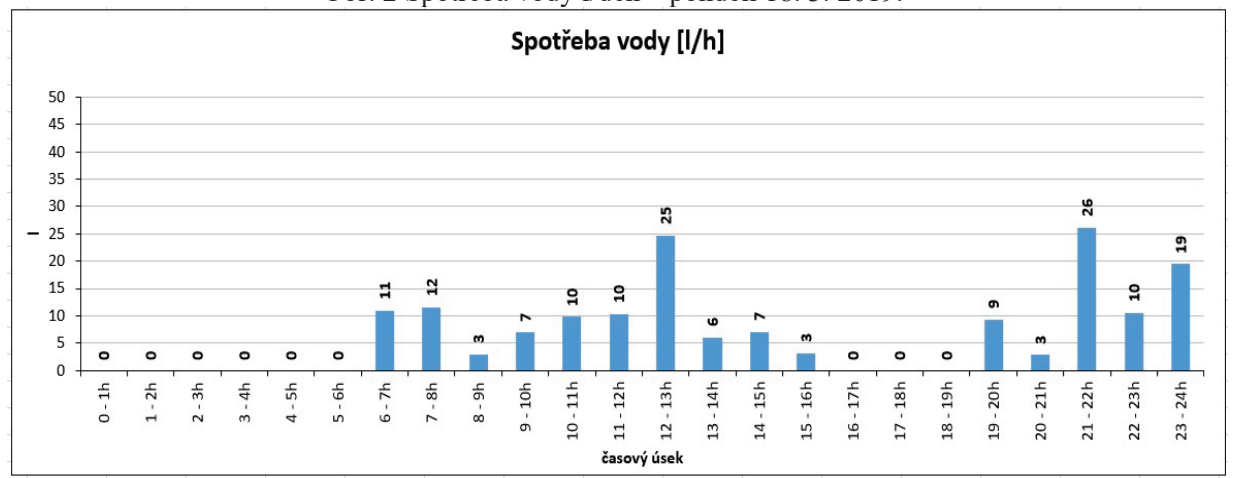

Obr. 3 Spotřeba vody 1/den - neděle 24. 3. 2019.

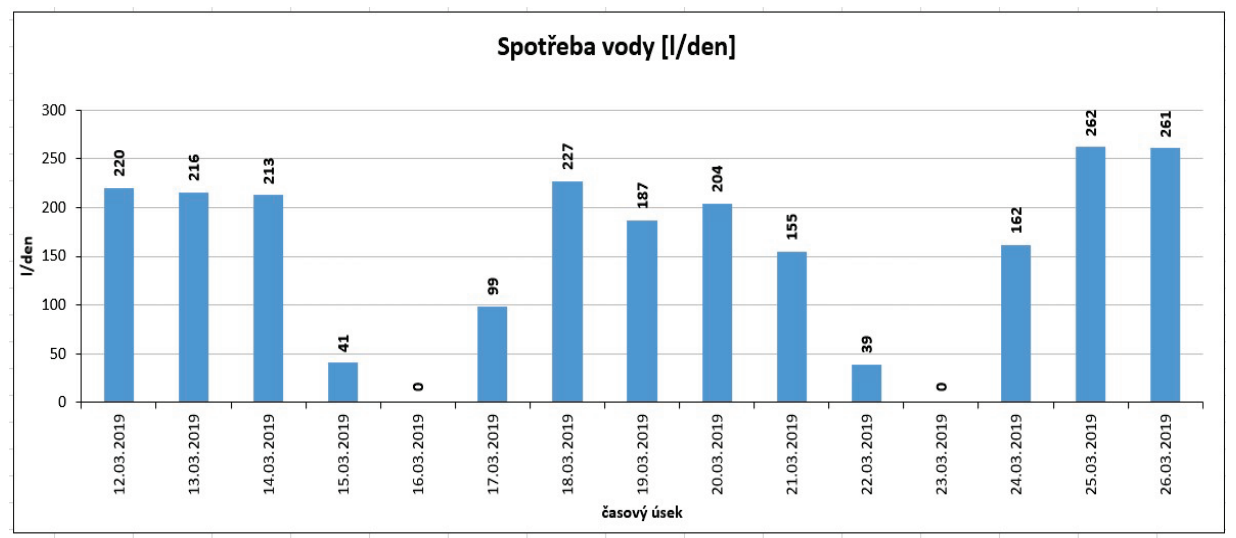

Obr. 4 Spotřeba vody 1/den - 12. 3. do 26. 3. 2019. 


\section{DISKUZE}

Provedl jsem interpretace vyhodnocených výsledků měření v objektu internátu a výsledky měření a vyhodnocení jsou uvedeny v grafech. Dř́ve nebyla vhodná kapacita úložišt' pro velké množství dat z měření, aby se mohlo provádět přesnější měření, a to měření každou sekundu.

V další fázi výzkumu se mohou provádět měření na různých typech budov s různými účely, aby tak mohla být v budoucnu provedeno vyhodnocení rentability využívání srážkových vod ve všech objektech. Zde se ovšem setkáváme s největším omezením výzkumné práce, jelikož ne všichni majitelé objektů jsou ochotni ke spolupráci a k prrístupu měření na jejich objektech, což znamená i částečný zásah do již provedeného potrubí vnitřního vodovodu.

Při vyhodnocení dat je patrné, že se potvrdily naše předpokládané závěry z měření. V objektu internátu nejsou o víkendech měřené zařizovací předměty př́liš využívány. V sobotu byly naměřeny nulové spotřeby vody. V současné době se provádí měření v jednotkách a desítkách sekund. Ve výše uvedených grafech vidíme hodnoty spotřeby vody zásobující nádržkové splachovače na WC v jednotlivých dnech i přes celé měřené období. Proto je jedinou správnou možností měření interval 1 sekundy.

V současné době, kdy je důležité zpětné využivání energií, šetření energií i snížení plýtvání vodou, je důležité se zamýšlet nad využíváním srážkových a šedých vod v objektu pro zásobování např. nádržkových splachovačů na WC.

Pro další výzkumnou práci je nutné tento interval měření dodržovat, aby byla měření co nejvíce směrodatná a dala se používat pro úpravy vztahů pro dimenzování vnitřních vodovodů, stanovení potřeby vody v objektu atd.

\section{ZÁVĚR}

Po vyhodnocení naměřených výsledků byly potvrzeny moje očekávané předpoklady a potvrdily se hypotézy z dřívějších výzkumných prací, kde jsme zjistili, že správné nastavení intervalu měření, je nedílnou součástí výzkumné práce. Pro nejpřesnější stanovení maximálních průtoků vody v objektech musí být nastavena odečet průtoku každou sekundu. Z naměřených dat můžeme dále vyhodnotit velké množství informací. V dané práci se zabývám vyhodnocením spotřeby vody v řešeném objektu internátu v Brně

Při dané výzkumné práci je možné i nadále pokračovat v měřeních na dalších objektech. V další fázi výzkumu se může provádět měření na různých typech budov s různými účely, tak aby se mohla zjistit rentabilita využívání srážkových vod pro investory, kteří mohou následně provést návrhy akumulačních nádrží na srážkovou vodu a tím snížit spotřebu pitné vody.

Naměřená data jsou využitelná pro přesnější a jednoduší návrh dimenzí vnitřních vodovodů a vodovodních př́pojek.

Měření mohlo být provedeno díky přidělenému specifickému výzkumu z Měření a analýzy špičkových průtoků a spotřeb vody $\mathrm{v}$ budovách.

\section{Poděkování}

Měření mohlo být provedeno díky přidělenému specifickému výzkumu z Měření a analýzy špičkových průtoků a spotřeb vody v budovách. FAST-J-20-6522

\section{Použité zdroje}

[1] Ing. VRÁNA, Jakub, Ph.D., Ing. MOŠTĚK Jan. Měření průtoků a spotřeb vody v bytových domech. SANHYGA 2019, 24. medzinárodná vedecko-technická konferencia. 2019, 10. 978-80-89878-49-9

[2] ČSN 755455 Výpočet vnitřních vodovodů. Úřad pro technickou normalizaci, metrologii a státní zkušebnictví. 2014

[3] Změna Z1 ČSN 755455 Výpočet vnitřních vodovodů. Česká agentura pro standardizaci. 2018

[4] Methods of Estimating Loads in Plumbing Systems, R. B. Hunter. 1940

[5] Measurements of water consumption in apartment buildings, B. Bleys, P. Van den Bossche, X. Kuborn. 2012 